\title{
Effect of pH on the Spontaneous Synthesis of Palladium Nanoparticles on Reduced Graphene Oxide
}

\author{
Xiaorui Zhang ${ }^{\mathrm{a}}$, Wataru Ooki ${ }^{\mathrm{b}}$, Yoshinori R. Kosaka ${ }^{\mathrm{b}}$, Akinori Okonogi ${ }^{\mathrm{b}}$, Galina Marzun ${ }^{\mathrm{c}, \mathrm{d}}$, Philipp Wagener ${ }^{\mathrm{c}, \mathrm{d}}$, \\ Stephan Barcikowski ${ }^{\text {c,d }}$, Takahiro Kondo ${ }^{\text {a,e }}$, Junji Nakamura ${ }^{\text {a,e* }}$ \\ ${ }^{\text {a }}$ Faculty of Pure and Applied Sciences, University of Tsukuba, 1-1-1 Tennodai, Tsukuba, Ibaraki 305-8573, Japan \\ ${ }^{\mathrm{b}}$ Graduate School of Pure and Applied Sciences, University of Tsukuba, 1-1-1 Tennodai, Tsukuba, Ibaraki 305-8573, Japan \\ ${ }^{\mathrm{c}}$ Technical Chemistry I and Center for Nanointegration Duisburg-Essen (CENIDE), University of Duisburg-Essen, \\ Universitaetsstrasse 7, D-45141 Essen, Germany \\ ${ }^{\mathrm{d}}$ NanoEnergieTechnikZentrum (NETZ), University of Duisburg-Essen, Carl-Benz-Strasse 199, D-47057 Duisburg, Germany \\ ${ }^{\mathrm{e}}$ Tsukuba Research Center for Interdisciplinary Materials Science (TIMS) \& Center for Integrated Research in Fundamental \\ Science and Engineering (CiRfSE), University of Tsukuba, 1-1-1 Tennodai, 305-8573, Japan \\ *nakamura@ims.tsukuba.ac.jp
}

(c) 2016. This manuscript version is made available under the Elsevier user license http://www.elsevier.com/open-access/userlicense/1.0/ 


\begin{abstract}
Palladium (Pd) nanoparticles were spontaneously deposited on reduced graphene oxide (rGO) without any external reducing agents. The prepared $\mathrm{Pd} / \mathrm{rGO}$ composites were then characterized by X-ray diffraction (XRD) and X-ray photoelectron spectroscopy (XPS). Spontaneous deposition occurred because of a redox reaction between the Pd precursor and rGO, which involved reduction of bivalent $\mathrm{Pd}$ to metallic $\mathrm{Pd}^{0}$ and oxidation of the $\mathrm{sp}^{2}$ carbon of $\mathrm{rGO}$ to oxygen-containing functional groups. The amount of Pd deposited on rGO varied with $\mathrm{pH}$, and this was attributed to electrostatic interactions between the Pd precursor and rGO based on the results of zeta potential measurements. The importance of the redox reaction in the spontaneous deposition was demonstrated in the experiment with $\mathrm{Zn}, \mathrm{Ni}, \mathrm{Cu}, \mathrm{Ag}, \mathrm{Pt}, \mathrm{Pd}$, and $\mathrm{Au}$.
\end{abstract}

\title{
Keywords
}

Reduced Graphene Oxide; Palladium Nanoparticle; Precursor; Redox Potential; Spontaneous Redox Deposition; Zeta Potential 


\section{Introduction}

Graphene, composed of regular $\mathrm{sp}^{2}$-bonded hexagonal carbon atoms, has high theoretical surface area $\left(2630 \mathrm{~m}^{2} \cdot \mathrm{g}^{-1}\right)$ and exceptional electrical conductivity $\left(2000 \mathrm{~S} \cdot \mathrm{cm}^{-1}\right)$ [1-6]. Graphene thus is a promising support for high loading of ultrafine catalyst particles, which may influence the catalytic properties of the metal particles. Recent research on metal/graphene catalysts has focused on a wide range of applications, including fuel cells [6-9], organic catalyst reactions [10-12], and environmental protection [13].

Reductants such as $\mathrm{NaBH}_{4}[14,15]$ and $\mathrm{N}_{2} \mathrm{H}_{4}$ [16], or surfactants such as polyvinylpyrrolidone $[17,18]$, are normally required for synthesis of metal/graphene catalysts. The use of these additives often requires multiple steps and makes the synthetic and purification protocols complex. In addition, the reductants pose environmental and health risks, while the surfactants can block the active catalytic sites of the metal. Recently, a facile and environmentally friendly synthesis that required no additional reductants or surfactants was introduced for depositing metals on carbon nanotubes [19]. A similar method has been applied to preparation of carbonbased support materials, including reduced graphene oxide (rGO), and graphene oxide (GO), decorated with metal nanoparticles (NPs) such as Pd, Pt, Ag, and Au [11, 20-28], and this method is referred to as spontaneous redox deposition.

Redox potential is believed to be the driving force behind spontaneous redox deposition of metals on carbon-based support materials [19]. However, most studies have focused on the formation of metal NPs, and transformation of the carbon-based support materials has not been investigated in detail. The transformation of carbon-based support materials, especially rGO, after spontaneous deposition of metals should be carefully examined because changes in the amount of the oxygen-containing functional groups could greatly affect the catalytic activity. In 
addition, electrostatic interactions between the metal precursor and $\mathrm{rGO}$ are affected by $\mathrm{pH}$, and this could affect the amount of metal deposited. Therefore, the effect of $\mathrm{pH}$ on spontaneous redox deposition should also be investigated.

In the present research, spontaneous redox deposition of Pd NPs on $\mathrm{rGO}$ in $\mathrm{H}_{2} \mathrm{O}$ was investigated systematically with changes in the $\mathrm{pH}$ of the Pd precursor solution. Possible oxidation reactions of $\mathrm{rGO}$ accompanying reduction of the Pd precursor are discussed.

\section{Experimental}

\subsection{Materials}

All chemicals were from commercial sources and used without further purification, including graphite powder (purity $>98 \%$; Wako Pure Chemical Industries, Osaka, Japan), sodium nitrate (purity $>99 \%$; Wako Pure Chemical Industries), sulfuric acid (purity $>95.1 \%$; Wako Pure Chemical Industries), potassium permanganate (purity $>99.3 \%$; Kanto Chemical Co., Tokyo, Japan) hydrogen peroxide (purity 30.0-35.5\%; Wako Pure Chemical Industries), hydrazine monohydrate, (purity $>98.0 \%$; Wako Pure Chemical Industries), and palladium(II) chloride (special grade; Wako Pure Chemical Industries).

\subsection{Preparation of $r G O$}

Graphite oxide was prepared from graphite powder by a modified Hummers' method $[6,8]$, briefly, the graphite powder was chemically oxidized to graphite oxide by $\mathrm{NaNO}_{3}, \mathrm{KMnO}_{4}$ and $\mathrm{H}_{2} \mathrm{SO}_{4}$. The obtained graphite oxide was dispersed in distilled water at a concentration of 2.0 $\mathrm{mg} / \mathrm{mL}$ and ultrasonicated for $5 \mathrm{~h}$ to form $\mathrm{GO}$ sheets. The $\mathrm{GO}$ sheets were reduced to $\mathrm{rGO}$ using hydrazine hydrate ( $1 \mathrm{~mL}$ for every $100 \mathrm{~mL}$ of $\mathrm{GO}$ solution). The obtained $\mathrm{rGO}$ was washed repeatedly with distilled water to remove any free reagents. Finally, the rGO was dried at $80{ }^{\circ} \mathrm{C}$. The characterization results of rGO are shown in Fig. S1. 


\subsection{Preparation of $P d N P$ s on $r G O$}

The $\mathrm{rGO}(30 \mathrm{mg})$ was dispersed in $50 \mathrm{~mL}$ of $\mathrm{H}_{2} \mathrm{O}$ by ultrasonication for $1 \mathrm{~h}$. Separate solutions of $\mathrm{PdCl}_{2}$ at different concentrations (the prescribed amounts of 5, 10, and $20 \mathrm{wt} \%$ compared with rGO) were also prepared in $50 \mathrm{~mL}$ of $\mathrm{H}_{2} \mathrm{O}$ and strongly agitated for $1 \mathrm{~h}$. The $\mathrm{pH}$ values of the $\mathrm{PdCl}_{2}$ solutions were adjusted to between 1 and 13 using $1 \mathrm{~mol} / \mathrm{L}$ (or $0.1 \mathrm{~mol} / \mathrm{L}$ ) $\mathrm{HCl}$ or $1 \mathrm{~mol} / \mathrm{L}$ $\mathrm{NaOH}$ aqueous solutions. Then, each $\mathrm{PdCl}_{2}$ precursor solution was mixed with the rGO solution, ultrasonicated $10 \mathrm{~min}$, and agitated on a magnetic stirrer. The prepared $\mathrm{Pd} / \mathrm{rGO}$ composites were isolated by vacuum filtration using a circulating aspirator (WJ-20, Sibata Scientific Technology, Saitama, Japan) and 0.2- $\mu \mathrm{m}$ membrane filter papers (Merck Millipore Ltd., Tokyo, Japan), followed by drying at $80^{\circ} \mathrm{C}$ in air.

\subsection{Characterization}

To investigate the surface charge and isoelectric point, the zeta potential of a rGO aqueous colloidal suspension was measured in a capillary cell $(750 \mu \mathrm{L})$ using electrophoretic light scattering (Zetasizer Nano ZS, Malvern Instruments, Malvern, UK). An automatic pH titration was performed with $1 \mathrm{~mol} / \mathrm{L} \mathrm{HCl}$ or $1 \mathrm{~mol} / \mathrm{L} \mathrm{NaOH}$, and the zeta potential, which is related to the mobility of particles in an electric field, was determined using the Smoluchowski equation [29]. Thermogravimetric differential thermal analysis measurements were carried out using a TG/DTA7300 (Seiko Instruments Inc., Chiba, Japan). Measurements were performed with an air flow of $200 \mathrm{~mL} / \mathrm{min}$. The temperature range was $25-1000{ }^{\circ} \mathrm{C}$, and the temperature was increased at a rate of $10{ }^{\circ} \mathrm{C} / \mathrm{min}$. X-ray diffraction (XRD) measurements were performed on a PANalytical PW 3050 Philips X'pert Pro with $\mathrm{Cu} \mathrm{K} \alpha$ radiation (1.541 $\AA$ ). The scan speed was $0.05^{\circ}$ /s (at $2 \theta$ ) up to $90^{\circ}$. A reflection-free Si plate was used as the sample stage. X-ray photoelectron spectroscopy (XPS) measurements were carried out using a JEOL JPS 9010 TR (Japan) with an 
$\mathrm{Al} \mathrm{K} \alpha(1486.6 \mathrm{eV}) \mathrm{X}$-ray source and a pass energy of $50 \mathrm{eV}$. The binding energy was calibrated based on the position of the $\mathrm{C} 1 \mathrm{~s}$ peak of graphite at $284.6 \mathrm{eV}$. Transmission electron microscopy (TEM) was carried out using a JEM-2100 at $200 \mathrm{kV}$. For TEM measurements, each Pd/rGO composite was dispersed in absolute ethanol by ultrasonication and then deposited on a support, which was a carbon film on a copper grid.

\section{Results and discussion}

TEM images were obtained of $\mathrm{rGO}$ and the $\mathrm{Pd} / \mathrm{rGO}$ prepared at $\mathrm{pH} 1$ with the prescribed amount of $20 \mathrm{wt} \%$ (Figs. 1 (a-d)). Curled and folded graphene can be seen in the TEM image of rGO (Fig. 1(a)). After Pd deposition, dark spots emerged on the rGO, and these were attributed to the Pd NPs (Fig. 1 (b-d)). The presence of Pd on the rGO was confirmed by the XPS survey scan of Pd/rGO (Fig. 1 (e) and Fig. S2). The size distribution of Pd NPs on the rGO (Fig. 1(f)) showed that the Pd NPs were on average $3.8 \mathrm{~nm}$ in diameter with a narrow size distribution. These results show that Pd NPs were spontaneously deposited on rGO in $\mathrm{H}_{2} \mathrm{O}$. 

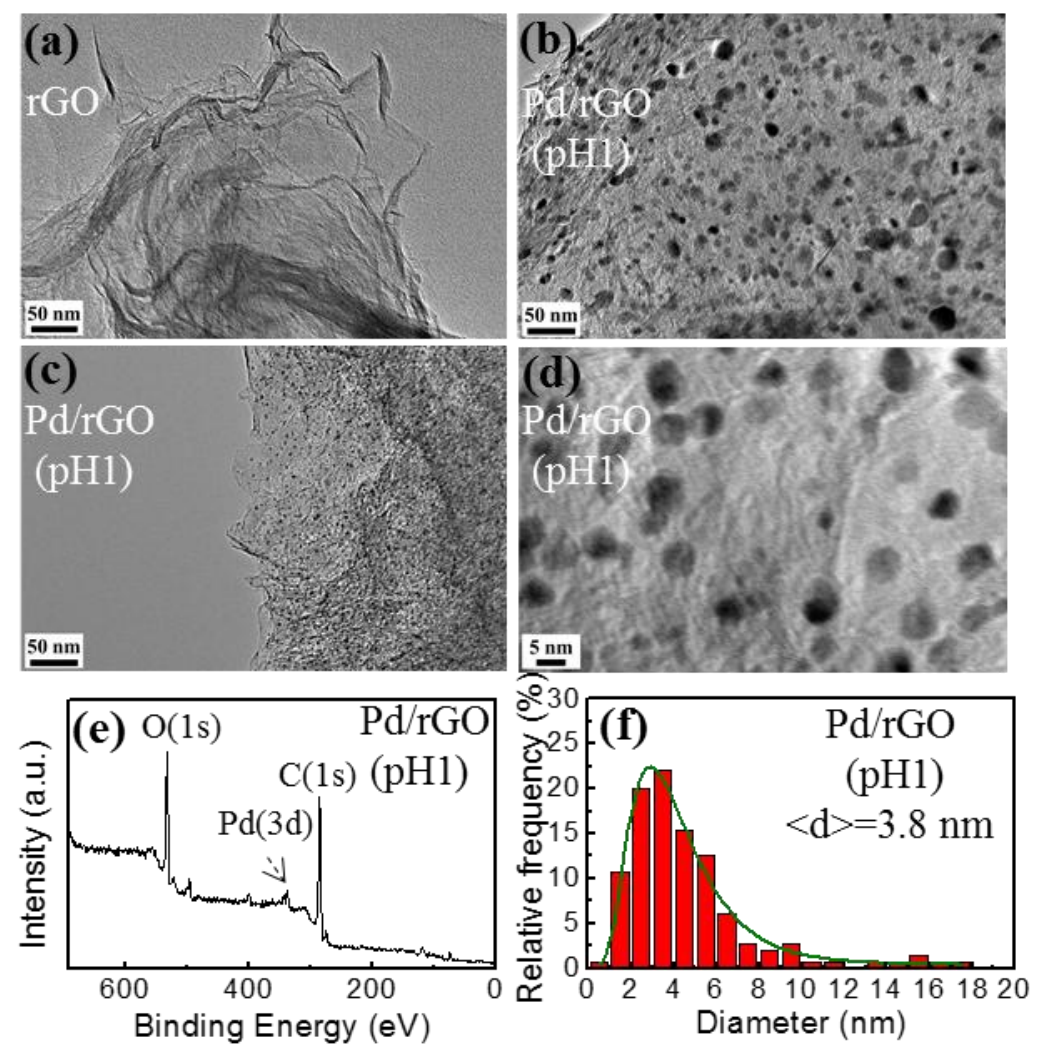

Fig. 1 (a) TEM image of rGO, (b-d) TEM images and (e) XPS survey scan of Pd/rGO prepared at $\mathrm{pH} 1$ with the prescribed amount of $20 \mathrm{wt} \%$, (f) histogram of the sizes of the Pd particles in the TEM images. $<\mathrm{d}>$ is the average particle size.

The amounts of Pd deposited on rGO at different $\mathrm{pH}$ values were determined by thermogravimetric differential thermal analysis (Fig. S3). Evaluation of the $\mathrm{pH}$ dependence of the amount of Pd deposited on rGO (Fig. 2(a)) showed that from pH 2-11 the amounts of Pd deposited on rGO were consistent with the prescribed amounts of Pd $(5,10$, and $20 \mathrm{wt} \%)$. By contrast, at $\mathrm{pH}$ values below 2 and above 11, the amounts of Pd deposited on rGO were lower than the prescribed amounts of Pd. Furthermore, the mean particle size of Pd NPs was calculated using Scherrer equation from XRD patterns for the $\mathrm{Pd} / \mathrm{rGO}$ composites with the prescribed amount of $20 \mathrm{wt} \%$ (Fig.S4). It showed that the mean particle size of Pd NPs is in the range of $33-53 \mathrm{~nm}$ from $\mathrm{pH} 2-11$, which it is $27 \mathrm{~nm}$ at $\mathrm{pH} 12$. 

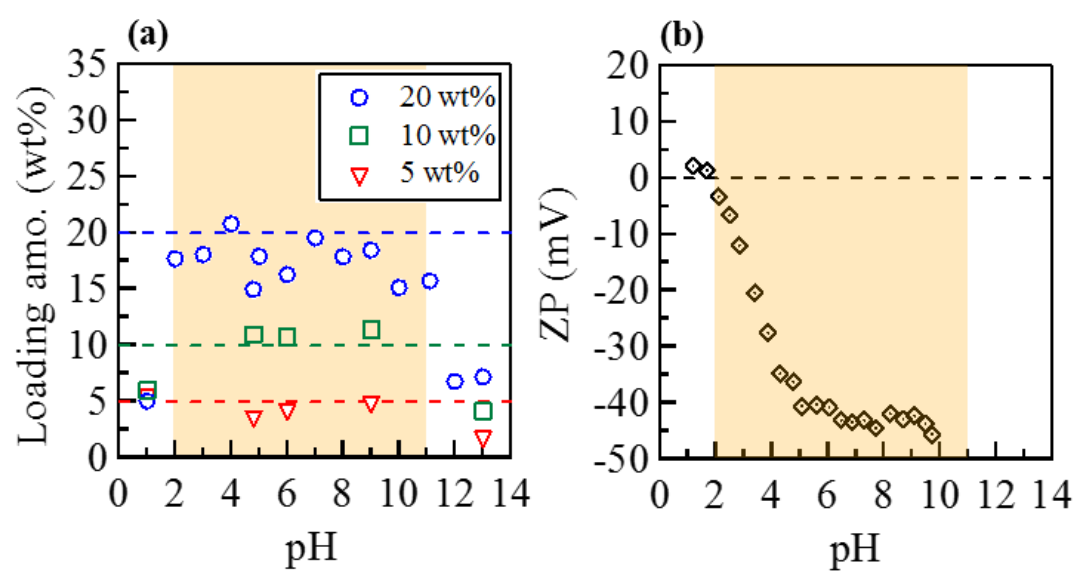

Fig. 2 (a) pH dependence of the amount of Pd deposited on rGO. The symbols show the amounts of Pd deposited, and the dashed lines show the prescribed amounts of Pd. (b) Changes in the zeta potential (ZP) of rGO with $\mathrm{pH}$.

To clarify the origin of the $\mathrm{pH}$ dependence of the amount of $\mathrm{Pd}$ deposited on $\mathrm{rGO}$, the zeta potential (net electrokinetic surface charge) of rGO was measured at different $\mathrm{pH}$ values. The zeta potential was positive below $\mathrm{pH} 1.8$ and negative above $\mathrm{pH} 1.8$ (Fig. 2(b)). From $\mathrm{pH} 1.8$ to $\mathrm{pH} 5$, the zeta potential decreased rapidly and then became stable above $\mathrm{pH} 5$. The isoelectric point of $\mathrm{rGO}$ was 1.8 . The zeta potential of $\mathrm{rGO}$ is affected by the gain or loss of protons $\left(\mathrm{H}^{+}\right)$by its oxygen-containing functional groups, such as $\mathrm{C}-\mathrm{O}-\mathrm{C}$ or $\mathrm{C}-\mathrm{OH}$. When $\mathrm{rGO}$ is dispersed in $\mathrm{H}_{2} \mathrm{O}$, its oxygen-containing functional groups will be ionized or hydrolyzed, for example,

$$
\begin{aligned}
& \mathrm{C}-\mathrm{OH} \rightleftharpoons \mathrm{C}-\mathrm{O}^{-}+\mathrm{H}^{+} \\
& \mathrm{C}-\mathrm{O}-\mathrm{C}+\mathrm{H}_{2} \mathrm{O} \rightleftharpoons \mathrm{C}-\mathrm{OH}^{+}-\mathrm{C}+\mathrm{OH}^{-}
\end{aligned}
$$

In addition, the species present in the aqueous Pd precursor solution will also be affected by $\mathrm{pH}$, and this can be evaluated using equilibrium constants (Table S1 and Fig. S5). In the present study, positively charged species, such as $\mathrm{Pd}^{2+}$ and $\mathrm{Pd}(\mathrm{OH})^{+}$, or soluble neutral species, such as $\mathrm{Pd}(\mathrm{OH})_{2}{ }^{0}$, were dominant below $\mathrm{pH} 11$. Above $\mathrm{pH} 11$, negatively charged $\mathrm{Pd}(\mathrm{OH})_{3}{ }^{-}$was 
dominant. Therefore, the $\mathrm{pH}$ dependence of the amount of $\mathrm{Pd}$ deposited on $\mathrm{rGO}$ is a combination of the effects on the zeta potential of rGO and the charge of the Pd ion. From pH 2-11, rGO and Pd ion have opposing charges, which results in electrostatic attraction. In this situation, negatively charged oxygen-containing functional groups serve as anchor sites for positively charged $\mathrm{Pd}$ ions, such as $\mathrm{Pd}^{2+}$ or $\mathrm{Pd}(\mathrm{OH})^{+}$, which leads to efficient adsorption of Pd ions onto rGO. However, when the $\mathrm{pH}$ is below 2 or above $11, \mathrm{rGO}$ and Pd ions in the precursor carry charges of the same sign; that is, positive charges below pH 2 and negative charges above $\mathrm{pH} 11$. This leads to electrostatic repulsion and means Pd ions cannot be efficiently adsorbed on rGO. It should be noted that small quantities of $\mathrm{Pd}(5 \mathrm{wt} \%)$ were deposited on the $\mathrm{rGO}$ at $\mathrm{pH}$ values below 2 and above 11. This probably occurred because a small number of species with opposite charges will be present on the rGO surface even when the net charge is positive $(\mathrm{pH}<2)$ or negative $(\mathrm{pH}>11)$. In any case, these results clearly show that the initial step of the spontaneous deposition is adsorption of Pd ions onto the charged oxygen-containing functional groups of rGO.

The XRD patterns of the $\mathrm{Pd} / \mathrm{rGOs}$ prepared at different $\mathrm{pH}$ values with the prescribed amounts of $20 \mathrm{wt} \%$ are shown in Fig. 3(a). Formation of metallic Pd NPs on the rGO from pH 2-11 was shown by the presence of the following XRD peaks: $\operatorname{Pd}(111)$ at $40.1^{\circ}, \operatorname{Pd}(200)$ at $46.7^{\circ}, \operatorname{Pd}(220)$ at $68.1^{\circ}$, and $\mathrm{Pd}(311)$ at $82.1^{\circ}$ (PDF \# 00-005-0681). The lack of metallic Pd peaks for Pd/rGO at $\mathrm{pH} 1$, and the weak peaks observed at $\mathrm{pH} 12$ and 13 were attributed to the small amounts of $\mathrm{Pd}$ deposited on rGO (Fig. 2(a)). Although Pd peaks were not detected in the XRD pattern for $\mathrm{Pd} / \mathrm{rGO}$ at $\mathrm{pH} 1$, the deposition of Pd was observed in TEM images and the XPS survey scan (Fig. 1). The formation of metallic Pd NPs on rGO indicates that the bivalent Pd species were reduced to metallic $\mathrm{Pd}^{0}$ even without any external reducing agent in $\mathrm{H}_{2} \mathrm{O}$. 
(a) XRD

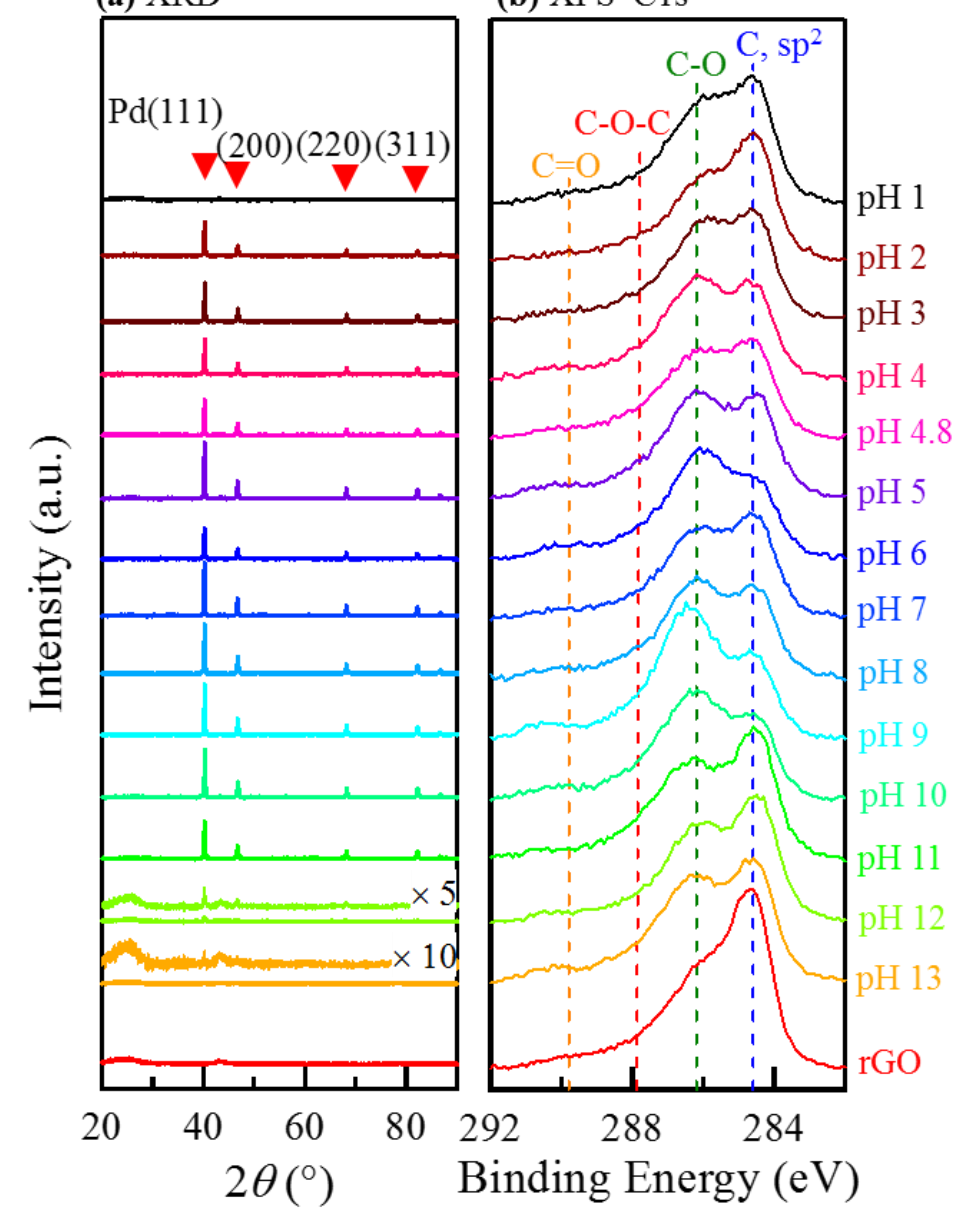

Fig. 3 (a) XRD patterns and (b) C1s XPS spectra for the Pd/rGOs prepared at different pH values with the prescribed amount of $20 \mathrm{wt} \%$, and rGO. Positions of metallic Pd peaks are marked with inverted triangles in the XRD patterns.

The results of our experiments suggested that rGO itself was the reducing agent for bivalent Pd. To verify this, the chemical state of $\mathrm{Pd} / \mathrm{rGO}$ was examined by XPS. Figure. 3(b) shows $\mathrm{C} 1 \mathrm{~s}$ spectra of $\mathrm{Pd} / \mathrm{rGO}$ prepared at different $\mathrm{pH}$ values. The $\mathrm{C} 1 \mathrm{~s}$ peaks were assigned as graphitic carbon $\left(\mathrm{sp}^{2}, 284.6 \mathrm{eV}\right), \mathrm{C}-\mathrm{O}(286.2 \mathrm{eV})$, epoxy carbon $(\mathrm{C}-\mathrm{O}-\mathrm{C}, 287.9 \mathrm{eV})$, and carbonyl carbon $(\mathrm{C}=\mathrm{O}, 289.8 \mathrm{eV})[30-36]$. Compared with the $\mathrm{C} 1 \mathrm{~s}$ spectrum of $\mathrm{rGO}$, all of the prepared $\mathrm{Pd} / \mathrm{rGOs}$ 
showed less intense graphitic carbon peaks and more intense $\mathrm{C} 1 \mathrm{~s}$ peaks at binding energies above $286 \mathrm{eV}$. This implies that rGO was oxidized during the spontaneous deposition of Pd NPs. Deconvolution of the C1s XPS spectra (Fig. S6) showed that the increase for $\mathrm{C}-\mathrm{O}$ was much larger than that for $\mathrm{C}-\mathrm{O}-\mathrm{C}$ or $\mathrm{C}=\mathrm{O}$. Therefore, the spontaneous deposition of $\mathrm{Pd}$ on $\mathrm{rGO}$ is suggested to occur through a redox reaction that involves reduction of the bivalent Pd precursor and oxidation of the rGO.

To confirm that the deposition occurred via a redox reaction, the amounts of oxygen and $\mathrm{Pd}$ were estimated (Fig. 4(a)) based on the XPS peak areas and taking into consideration atomic sensitivity. The amounts of oxygen and $\mathrm{Pd}$ increased with increasing $\mathrm{pH}$ up to $\mathrm{pH} 7$, and then decreased above $\mathrm{pH}$ 7. This indicates that the concentration of oxygen species in $\mathrm{rGO}$ corresponds to the amount of Pd deposited.
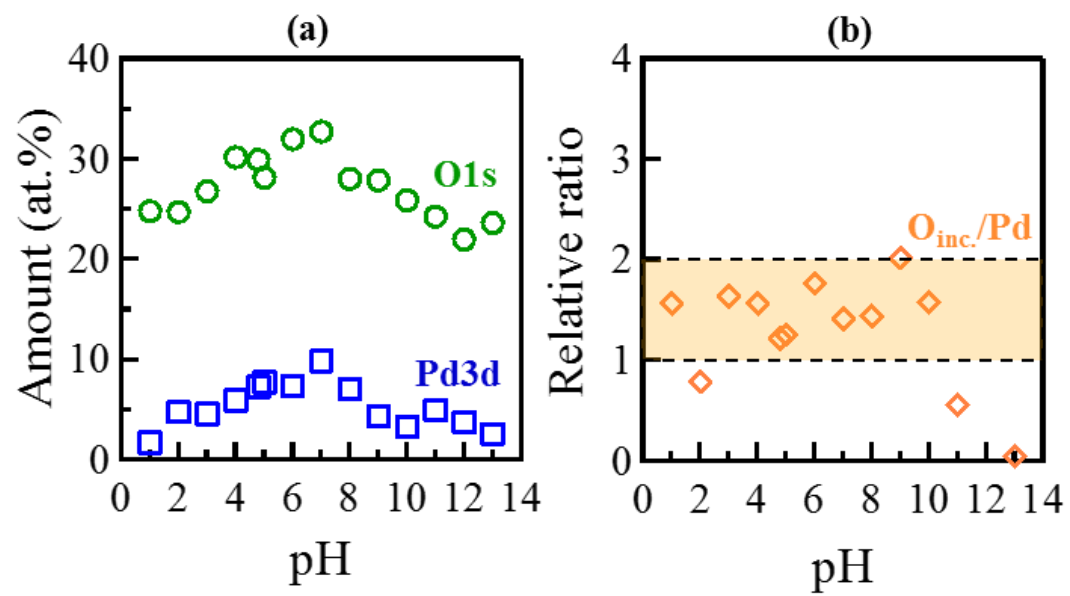

Fig. 4 (a) Amount (at.\%) of $\mathrm{O} 1 \mathrm{~s}$ and $\mathrm{Pd} 3 \mathrm{~d}$ and (b) $\mathrm{O}_{\text {increased (inc.) }} / \mathrm{Pd}$ relative ratio $\left(\mathrm{O}_{\text {inc. }}\right.$ means the increased oxygen amount of rGO by Pd deposition, Supporting Information) of the Pd/rGO composites with the prescribed amount of $20 \mathrm{wt} \%$.

The relative ratio of $\mathrm{O}_{\text {inc. }} / \mathrm{Pd}$ was between one and two at most $\mathrm{pH}$ values (Fig. 4(b)). This indicates that when one Pd atom was deposited on the surface of rGO, one or two oxygen atoms 
formed in the rGO. In the redox reaction, the oxidation of rGO releases electrons, which are used in the reduction of the Pd precursor as follows: $\mathrm{Pd}^{2+}+2 \mathrm{e}^{-} \rightarrow \mathrm{Pd}^{0}$. Possible oxidation reactions of rGO are shown below.

$$
\begin{aligned}
& 2 \mathrm{C}\left(\mathrm{C} 1 \mathrm{~s} \mathrm{sp}^{2} \text { in } \mathrm{rGO}\right)+\mathrm{H}_{2} \mathrm{O} \rightarrow \mathrm{C}-\mathrm{O}-\mathrm{C}+2 \mathrm{H}^{+}+2 \mathrm{e}^{-} \\
& \mathrm{C}\left(\mathrm{C} 1 \mathrm{~s} \mathrm{sp}{ }^{2} \text { in } \mathrm{rGO}\right)+\mathrm{H}_{2} \mathrm{O} \rightarrow \mathrm{C}=\mathrm{O}+2 \mathrm{H}^{+}+2 \mathrm{e}^{-} \\
& \mathrm{C}\left(\mathrm{C} 1 \mathrm{~s} \mathrm{sp}^{2} \text { in } \mathrm{rGO}\right)+\mathrm{H}_{2} \mathrm{O} \rightarrow \mathrm{C}-\mathrm{OH}+\mathrm{H}^{+}+\mathrm{e}^{-}
\end{aligned}
$$

In these reactions, protons $\left(\mathrm{H}^{+}\right)$are released, which decreases the $\mathrm{pH}$. Indeed, when the rGO aqueous colloidal suspension was mixed with the Pd precursor, the $\mathrm{pH}$ decreased (Fig. S7).

Generally, a redox reaction involves transfer of electrons from one substance to another, and its spontaneity can be determined from the redox potentials. For a spontaneous redox reaction, the redox potential of the cathodic reaction should be higher than that of the anodic reaction. For $\mathrm{Pd} / \mathrm{rGO}$, the standard reduction potential of $\mathrm{Pd}^{2+} / \mathrm{Pd}^{0}(0.92 \mathrm{~V}$ vs. the standard hydrogen electrode (SHE) [37]) is higher than that of $\mathrm{GO} / \mathrm{rGO}(0.25 \mathrm{~V}$ [25] or $0.38 \mathrm{~V}$ [23] vs. the SHE).

Accordingly, the $\mathrm{rGO} / \mathrm{Pd}^{2+}$ system undergoes spontaneous oxidation and reduction in $\mathrm{H}_{2} \mathrm{O}$ without any external reducing agent, as observed in these experiments.

As described above, the spontaneous redox deposition involved two important steps, which were approach of the metal precursor to $\mathrm{rGO}$, and the redox reaction. The approach of metal precursor to rGO was greatly affected by $\mathrm{pH}$. Thus the amount of Pd deposited on $\mathrm{rGO}$ was affected by the $\mathrm{pH}$. The spontaneity of NP formation was governed by the redox potential. Table 1 shows the standard reduction potentials vs the SHE for several metal precursors and rGO. These potentials suggest that $\mathrm{Zn}, \mathrm{Ni}$, and $\mathrm{Cu}$ could not be spontaneously deposited on rGO, while $\mathrm{Au}, \mathrm{Pd}, \mathrm{Pt}$, and $\mathrm{Ag}$ could be spontaneously deposited on rGO via a redox reaction. To verify this, we conducted a spontaneous redox deposition experiment with $\mathrm{Zn}, \mathrm{Ni}, \mathrm{Cu}, \mathrm{Pt}$, and $\mathrm{Pd}$ by mixing 
the precursor solution including each metal with the rGO aqueous colloidal suspension without any external reducing agents. The results are summarized in Fig. S8. Compared with the amounts of $\mathrm{Pt}$ and $\mathrm{Pd}$ deposited on $\mathrm{rGO}$, little $\mathrm{Zn}$, Ni, or $\mathrm{Cu}$ was detected on rGO.

Table 1 Standard reduction potentials vs the SHE at $298 \mathrm{~K}$.

\begin{tabular}{lll}
\hline Half-reaction & $\mathbf{E}^{\mathbf{0}} / \mathbf{V}$ & Metal deposition $^{\mathbf{a}}$ \\
\hline $\mathrm{Zn}^{2+}+2 \mathrm{e}^{-} \rightarrow \mathrm{Zn}$ & $-0.76[38]$ & $\mathrm{N}$ \\
$\mathrm{Ni}^{2+}+2 \mathrm{e}^{-} \rightarrow \mathrm{Ni}$ & $-0.23[38]$ & $\mathrm{N}$ \\
$\mathrm{Cu}^{2+}+2 \mathrm{e}^{-} \rightarrow \mathrm{Cu}$ & $0.34[38]$ & $\mathrm{N}$ \\
$\mathrm{Ag}^{+}+\mathrm{e}^{-} \rightarrow \mathrm{Ag}$ & $0.80[38]$ & $\mathrm{Y}[22,27]$ \\
$\mathrm{PtCl}_{4}^{2-}+2 \mathrm{e}^{-} \rightarrow \mathrm{Pt}+4 \mathrm{Cl}^{-}$ & $0.76[37]$ & $\mathrm{Y}$ \\
$\mathrm{Pd}^{2+}+2 \mathrm{e}^{-} \rightarrow \mathrm{Pd}$ & $0.92[37]$ & $\mathrm{Y}$ \\
$\mathrm{Au}^{3+}+3 \mathrm{e}^{-} \rightarrow \mathrm{Au}$ & $1.40[38]$ & $\mathrm{Y}[23,27]$ \\
\hline
\end{tabular}

\footnotetext{
${ }^{\mathrm{a}} \mathrm{N}$ indicates that no spontaneous redox deposition on $\mathrm{rGO}$ occurred, and $\mathrm{Y}$ indicates that spontaneous redox deposition on rGO occurred.
}

\section{Conclusions}

In summary, metallic Pd NPs were spontaneously deposited on $\mathrm{rGO}$ in $\mathrm{H}_{2} \mathrm{O}$ without any reducing agents. The amount of $\mathrm{Pd}$ deposited on $\mathrm{rGO}$ was dependent on the $\mathrm{pH}$. Spontaneous redox deposition involved the following two pivotal processes: first, the approach of Pd ions to rGO, which was electrokinetically controlled by the $\mathrm{pH}$ of the aqueous solution; and second, a redox reaction for reducing the bivalent $\mathrm{Pd}$ precursor and oxidation of $\mathrm{rGO}$. The amount of $\mathrm{Pd}$ NPs deposited on rGO was determined by the electrostatic interaction between the Pd precursor and rGO. The spontaneity was determined by the redox potential difference between the Pd precursor and rGO. The importance of the redox reaction in the spontaneous deposition was demonstrated in the experiment with $\mathrm{Zn}, \mathrm{Ni}, \mathrm{Cu}, \mathrm{Ag}, \mathrm{Pt}, \mathrm{Pd}$, and $\mathrm{Au}$. 


\section{Acknowledgment}

This work was supported by the ACT-C, and the JST.

Supporting Information. Characterization of rGO, XPS survey scan of $\mathrm{Pd} / \mathrm{rGO}$, TG curves of $\mathrm{Pd} / \mathrm{rGO}, \mathrm{pH}$ dependence of the mean particle size of Pd NPs, Effect of $\mathrm{pH}$ on the species present in the $\mathrm{PdCl}_{2}$ precursor solution, Deconvolution of the C1s XPS spectra, Calculation of the of $\mathrm{O}_{\text {increased (inc.) }} / \mathrm{Pd}$ relative ratio, Changes in the $\mathrm{pH}$ during spontaneous redox deposition of $\mathrm{Pd}$ on rGO, and Investigation of the deposition of multiple metals on rGO.

\section{References}

[1] M. Liu, R. Zhang, W. Chen, Graphene-supported nanoelectrocatalysts for fuel cells: synthesis, properties, and applications., Chem. Rev. 114 (2014) 5117-5160.

[2] X. Wang, L. Zhi, K. Müllen, Transparent, conductive graphene electrodes for dyesensitized solar cells., Nano Lett. 8 (2008) 323-327.

[3] X. Li, G. Zhang, X. Bai, X. Sun, X. Wang, E. Wang, H. Dai, Highly conducting graphene sheets and Langmuir-Blodgett films., Nat. Nanotechnol. 3 (2008) 538-542.

[4] M.J. Allen, V.C. Tung, R.B. Kaner, Honeycomb carbon: a review of graphene., Chem. Rev. 110 (2010) 132-145.

[5] Z.-S. Wu, W. Ren, L. Gao, J. Zhao, Z. Chen, B. Liu, D. Tang, B. Yu, C. Jiang, H.-M. Cheng, Synthesis of graphene sheets with high electrical conductivity and good thermal stability by hydrogen arc discharge exfoliation., ACS Nano. 3 (2009) 411-417.

[6] R. Siburian, T. Kondo, J. Nakamura, Size Control to a Sub-Nanometer Scale in Platinum Catalysts on Graphene, J. Phys. Chem. C. 117 (2013) 3635-3645. 
[7] H. Huang, X. Wang, Recent progress on carbon-based support materials for electrocatalysts of direct methanol fuel cells, J. Mater. Chem. A. 2 (2014) 6266-6291.

[8] R. Siburian, J. Nakamura, Formation Process of Pt Subnano-Clusters on Graphene Nanosheets, J. Phys. Chem. C. 116 (2012) 22947-22953.

[9] E. Yoo, T. Okata, T. Akita, M. Kohyama, J. Nakamura, I. Honma, Enhanced electrocatalytic activity of Pt subnanoclusters on graphene nanosheet surface, Nano Lett. 9 (2009) 2255-2259.

[10] Y. Li, X. Fan, J. Qi, J. Ji, S. Wang, G. Zhang, F. Zhang, Palladium nanoparticle-graphene hybrids as active catalysts for the Suzuki reaction, Nano Res. 3 (2010) 429-437.

[11] N. Zhang, H. Qiu, Y. Liu, W. Wang, Y. Li, X. Wang, J. Gao, Fabrication of gold nanoparticle/graphene oxide nanocomposites and their excellent catalytic performance, J. Mater. Chem. 21 (2011) 11080-11083.

[12] J. Hu, Y. Wang, M. Han, Y. Zhou, X. Jiang, P. Sun, A facile preparation of palladium nanoparticles supported on magnetite/s-graphene and their catalytic application in SuzukiMiyaura reaction, Catal. Sci. Technol. 2 (2012) 2332-2340.

[13] V. Chandra, J. Park, Y. Chun, J.W. Lee, I. Hwang, K.S. Kim, Water-Dispersible Magnetite-Reduced Graphene Oxide Composites for Arsenic Removal, ACS Nano. 4 (2010) 3979-3986.

[14] Y. Li, Y. Li, E. Zhu, T. McLouth, C.-Y. Chiu, X. Huang, Y. Huang, Stabilization of High Performance ORR Pt Electrocatalyst Supported on Reduced Graphene Oxide (RGO)/Carbon Black (CB) Composite, J. Am. Chem. Soc. 134 (2012) 12326-12329. 
[15] B. Seger, P. V. Kamat, Electrocatalytically Active Graphene-Platinum Nanocomposites. Role of 2-D Carbon Support in PEM Fuel Cells, J. Phys. Chem. C. 113 (2009) 79907995.

[16] R. Nie, J. Wang, L. Wang, Y. Qin, P. Chen, Z. Hou, Platinum supported on reduced graphene oxide as a catalyst for hydrogenation of nitroarenes, Carbon N. Y. 50 (2012) $586-596$.

[17] F. Xu, Y. Sun, Y. Zhang, Y. Shi, Z. Wen, Z. Li, Graphene-Pt nanocomposite for nonenzymatic detection of hydrogen peroxide with enhanced sensitivity, Electrochem. Commun. 13 (2011) 1131-1134.

[18] S. Guo, S. Dong, E. Wang, Three-dimensional Pt-on-Pd bimetallic nanodendrites supported on graphene nanosheet: facile synthesis and used as an advanced nanoelectrocatalyst for methanol oxidation., ACS Nano. 4 (2010) 547-555.

[19] H.C. Choi, M. Shim, S. Bangsaruntip, H. Dai, Spontaneous Reduction of Metal Ions on the Sidewalls of Carbon Nanotubes, J. Am. Chem. Soc. 124 (2002) 9058-9059.

[20] X. Chen, G. Wu, J. Chen, X. Chen, Z. Xie, X. Wang, Synthesis of "clean" and welldispersive Pd nanoparticles with excellent electrocatalytic property on graphene oxide., J. Am. Chem. Soc. 133 (2011) 3693-3695.

[21] F. Li, Y. Guo, R. Li, F. Wu, Y. Liu, X. Sun, C. Li, W. Wang, J. Gao, A facile method to synthesize supported Pd-Au nanoparticles using graphene oxide as the reductant and their extremely high electrocatalytic activity for the electrooxidation of methanol and ethanol, J. Mater. Chem. A. 1 (2013) 6579-6587. 
[22] X. Zhou, X. Huang, X. Qi, S. Wu, C. Xue, F.Y.C. Boey, Q. Yan, P. Chen, H. Zhang, In Situ Synthesis of Metal Nanoparticles on Single-Layer Graphene Oxide and Reduced Graphene Oxide Surfaces, J. Phys. Chem. C. 113 (2009) 10842-10846.

[23] B.S. Kong, J. Geng, H.T. Jung, Layer-by-layer assembly of graphene and gold nanoparticles by vacuum filtration and spontaneous reduction of gold ions., Chem. Commun. (2009) 2174-2176.

[24] H. Yin, H. Tang, D. Wang, Y. Gao, Z. Tang, Facile Synthesis of Surfactant-Free Au Cluster/Graphene Hybrids for High- PerformanceOxygen Reduction Reaction, ACS Nano. 6 (2012) 8288-8297.

[25] T. Sun, Z. Zhang, J. Xiao, C. Chen, F. Xiao, S. Wang, Y. Liu, Facile and green synthesis of palladium nanoparticles-graphene-carbon nanotube material with high catalytic activity., Sci. Rep. 3 (2013) 2527.

[26] G. Wu, H. Huang, X. Chen, Z. Cai, Y. Jiang, X. Chen, Facile synthesis of clean Pt nanoparticles supported on reduced graphene oxide composites: Their growth mechanism and tuning of their methanol electro-catalytic oxidation property, Electrochim. Acta. 111 (2013) 779-783.

[27] A. Mondal, N.R. Jana, Surfactant-Free, Stable Noble Metal-Graphene Nanocomposite as High Performance Electrocatalyst, ACS Catal. 4 (2014) 593-599.

[28] G. Marzun, J. Nakamura, X. Zhang, S. Barcikowski, P. Wagener, Size control and supporting of palladium nanoparticles made by laser ablation in saline solution as a facile route to heterogeneous catalysts, Appl. Surf. Sci. 348 (2015) 75-84. 
[29] A. Sze, D. Erickson, L. Ren, D. Li, Zeta-potential measurement using the Smoluchowski equation and the slope of the current-time relationship in electroosmotic flow, J. Colloid Interface Sci. 261 (2003) 402-410.

[30] Y. Yoon, K. Lee, C. Baik, H. Yoo, M. Min, Y. Park, S.M. Lee, H. Lee, Anti-Solvent Derived Non-Stacked Reduced Graphene Oxide for High Performance Supercapacitors, Adv. Mater. 25 (2013) 4437-4444.

[31] Y. Zhu, M.D. Stoller, W. Cai, A. Velamakanni, R.D. Piner, D. Chen, R.S. Ruoff, Exfoliation of Graphite Oxide in Propylene Carbonate and Thermal Oxide Platelets, ACS Nano. 4 (2010) 1227-1233.

[32] D. Yang, A. Velamakanni, G. Bozoklu, S. Park, M. Stoller, R.D. Piner, S. Stankovich, J. Inhwa, D.A. Field, C.A. Ventrice, R.S. Ruoff, Chemical analysis of graphene oxide films after heat and chemical treatments by X-ray photoelectron and Micro-Raman spectroscopy, Carbon N. Y. 47 (2009) 145-152.

[33] S. Wang, D. Yu, L. Dai, D.W. Chang, J. Baek, Polyelectrolyte-Functionalized Graphene as Metal-Free Electrocatalysts for Oxygen Reduction, ACS Nano. 5 (2011) 6202-6209.

[34] Y. Fang, B. Luo, Y. Jia, X. Li, B. Wang, Q. Song, F. Kang, L. Zhi, Renewing functionalized graphene as electrodes for high-performance supercapacitors., Adv. Mater. 24 (2012) 6348-6355.

[35] C. Xu, X. Wang, J. Zhu, Graphene - Metal particle nanocomposites, J. Phys. Chem. C. 112 (2008) 19841-19845. 
[36] M. Koinuma, H. Tateishi, K. Hatakeyama, S. Miyamoto, C. Ogata, A. Funatsu, T. Taniguchi, Y. Matsumoto, Analysis of Reduced Graphene Oxides by X-ray Photoelectron Spectroscopy and Electrochemical Capacitance, Chem. Lett. 42 (2013) 924-926.

[37] A.J. Bard, L.R. Faulkner, Electrochemical Methods -Fundamentals and Applications, second edi, John Wiley \& Sons, Inc., New York, 2001.

[38] P. Atkins, J. De Paula, Physical Chemistry, Eighth Edi, Oxford University Press, New York, 2006. 